\title{
An Analysis of Students' Grammatical Errors in Writing Procedure Texts
}

\author{
Ihda Husnayaini ${ }^{1}$, M. Thaib Rizki ${ }^{2}$, Chindy Savitri ${ }^{3}$ \\ ${ }^{1}$ IAIN Syaikh Abdurrahman Siddik Bangka Belitung \\ ${ }^{2}$ IAIN Syaikh Abdurrahman Siddik Bangka Belitung \\ ${ }^{3}$ IAIN Syaikh Abdurrahman Siddik Bangka Belitung
}

\section{Keywords:}

Error Analysis

Grammatical Errors

Gender

\begin{abstract}
This study investigated the common types of grammatical errors made by $3^{\text {rd }}$ grade of secondary male and female students at SMP Muhammadiyah Pangkalpinang in writing procedure texts and to find out whether there was any significant difference in the errors committed by the students when grouped according to gender. The researcher specified this study in writing procedure text which focused on their errors. The research method used was quantitative. The samples of this study were 30 students that were taken from $9^{\text {th }}$ grade of SMP Muhammadiyah Pangkalpinang, Bangka Belitung Province. The data was obtained from the sentences written by the students and by means of the test. In this study, the result of the test was analyzed by paired sample t-test. In accordance with the result analysis, the study revealed two major findings. The result showed that there was a significant difference in the errors committed by the students when grouped according to gender. Therefore, the data further means that gender affects the number, and percentage of errors committed by the students.
\end{abstract}

Correspondence:

Ihda Husnayaini

Email: ida12puerta@gmail.com

\section{Introduction}

In recent years, many studies have been discussed and conducted the issues about the differences of gender, among men and women from different perspectives, and language has not been an exception as a social phenomenon and a need for human beings to communicate. Language in this global era has a great role and it could never be undermined. Whether one aims for a simply reason to survive, as a needed in a social life, as a means of connecting people to get information, she would find herself in this era in a situation which would demand language skills, be it speaking, reading, listening, and writing. Holmes and Meyerhoff stated that, life stage and gender are related each other (Meyerhoff \& Holmes, 2003). The difference of gender in language ability is finding that boys tend to develop language disorders such as stuttering than girls and also gender is not only related to something we are born with, and something we have but gender is related to something we do and we perform (Eckert \& McConnell-Ginet, 2003).

Gender does not simply represent biological individuality or an individual tendency to be a particular kind of person, rather it is a social arrangement which is decided by the nature of the gender order and individual's connection to it (M. Holmes, 2007). The overwhelming fact about gender is that it is omnipresent. Children get gender from everywhere (Ruble, Martin, \& Berenbaum, 2007). Gender is a pattern of relations which has developed over time to define masculinity and femininity, male and female, thereby regulating people's relation to society (Blakemore, Berenbaum, \& Liben, 2013; Marianne, 2011; Martin \& Ruble, 2010). The notion of gender presents in every aspect of society, in institutions, public spaces, clothing, in art, etc. It is embedded in the neighborhood, family, school, the media, and so on and all of them are structurally related (Rocheleau, Thomas-Slayter, \& Wangari, 2016). 
Gender, which is complicatedly organized might establish a connection between a girl's desire for frilly party dress and the man's control it (Marianne, 2011). It is an unlimited connection that makes language very important to gender and vice versa (Cameron, 2010). Our interactions are mostly inspired by gender and those interactions strengthen their role in supporting gender (J. Holmes \& Meyerhoff, 2008).

English, on the other hand, is one of many languages that should be learned and mastered by people in order to help us to get higher education abroad, to get a job, to get a chance to be a participant of international competitions. In other countries, English is known and used as foreign language, and some countries regard it as their second language. By learning, knowing and mastering more than one language, it requires knowledge and understanding towards those languages. In learning English itself, students have to learn and master English either oral or written. Sometimes, we often hear and see that students find hard to express their ideas, thoughts in good organization of writing due to the differences between mother tongue and foreign language. According to Nunan, the writing process is clearly complex and a difficult activity for most people, both in mother tongue and foreign language because in the writing process, there are a number of language aspects that is involved such as prepositions, spell-check, model texts and grammar (David, 1991). In order to convey ideas appropriately and correctly in writing English, writers are required to master grammar as the primary rules of a language. By following and mastering the grammatical rules, learners are able to write a correct language (Lynch \& Anderson, 2013).

Brown stated that, grammar is interconnected to form, meaning and use (Brown, 2000). Generally, grammar plays an important role in a language and it becomes more difficult when it is used in writing. According to Pekka Saaristo, grammar has an important role in a language because it guides how language should be spoken or written in a correct way because without grammar one cannot write or speak correctly (Saaristo, 2015). The differences in the system of mother tongue and foreign language seems to be a challenge for language learners in writing English. Thus, when foreign language learners compose English writing, most of them unsurprisingly produce different types of errors. Nonetheless, the assumption of language proficiency among female and male learners is so different. Larsen and Long stated that, in second language learners, females are better than males (Larsen-Freeman \& Long, 2014). It can be inferred that grammar has a great role in a language and it seems impossible without knowing and learning the grammar as it is a part of a language that is interconnected with form, meaning and use. The existence of grammar rules is very important for foreign language learners and by following and mastering it they are able to write a correct and appropriate language. Although grammar is not the main objective of language learning but it is still needed in the classroom and it becomes a prerequisite step before learning how to use and practice the language.

In accordance with the syllabus, procedure text is taught for the third grade of secondary school in Indonesia. Considering the explanation above, the researcher had done the preliminary research of the $9^{\text {th }}$ graders. They have learnt about procedure text when they were in the second grade and it is reviewed when they are in the third grade and they also have learnt about simple present tense which is used and known as language features in procedure text but they still made errors in writing procedure texts. The problems faced by the teacher and the students were known in some indicators, as follows:

1. Based on the preliminary research that had been given by the researcher in a form essay, the researcher found that 118 students made errors in writing simple present tense, procedure text and Expressions (Asking for and Showing Certainty, Uncertainty; Expressing and Responding to Doubt). They always use unnecessary and inappropriate vocabularies. The students of the ninth grade are students who learn English as the foreign language. There is a case of examples that the researcher found the errors made by the student in the writing a procedural text: "To pour one cup of water". One of the students did not realize that she made an error. The correct sentence in writing procedure text should be "pour one glass of water". There is also a case of examples that the researcher found the errors made by the student in writing Simple Present Tense: "We do go to school every morning?". Instead of "Do we go to school every morning?. The last example that the researcher found the error made by the student in writing Asking for and Showing Certainty, Uncertainty: "Are you sure about it? Yes. It is confirm. Instead of "Are you sure about it? Yes. It is confirmed" 
Table 1

(The mean of the Result of the Writing Test of the Ninth Grade)

\begin{tabular}{|c|c|c|c|c|c|}
\hline No & Class & $\begin{array}{c}\text { The } \\
\text { Number } \\
\text { of the } \\
\text { Students }\end{array}$ & $\begin{array}{c}\text { Simple } \\
\text { Present } \\
\text { Tense }\end{array}$ & $\begin{array}{c}\text { Expressions } \\
\text { Procedure } \\
\text { Texts } \\
\text { (Asking for } \\
\text { and Showing } \\
\text { Certainty and } \\
\text { Uncertainty) }\end{array}$ \\
\hline 1 & IX A & 39 & 68 & 32 & 50 \\
\hline 2 & IX B & 39 & 73 & 35 & 45 \\
\hline 3 & IX C & 40 & 75 & 44 & 58 \\
\hline \multicolumn{7}{|c|}{ T18 } \\
\multicolumn{7}{|l}{ Tource: SMP Muhammadiyah Pangkalpinang (2019/2020) } \\
\hline
\end{tabular}

2. Based on the interview with the English teacher, the students have low understanding in English. In teaching English, drilling and repetition are the ways for the English teacher to teach the students in order to make them understand more about English. If the students still make mistakes then the teacher keeps giving them exercises until they do not make many mistakes. It is common and natural for students to make mistakes in the process of language learning. However, it would be better if the students do not make many mistakes because English is totally different with Bahasa Indonesia, every word in English has its own meaning and when we write incorrectly even one until two letters, the meaning might be different. The students of the ninth grade have learnt grammar and its rules but seldom put about that knowledge to practical use and they do not pay attention more to their mistakes.

Considering the fact above, it leads the researcher to analyze, identify and quantify their grammatical errors in order to anticipate and minimize their errors in the future. Marites Quibol Catabay concluded his or her result, by analyzing the errors that students make it could be useful for them to increase their ability and it could enable the students to be aware of common grammatical errors that they make (QuibolCatabay, 2016). Charanjit concluded that, error analysis could be significant, first for the teachers, by knowing and understanding the students' weakness or errors in writing, it provides information for the teachers to help their students to make better essay writing by modifying their teaching style based on what the students' need and writing errors. Second, for the students, it provides evidence of how far their competence in English (Singh, Singh, Razak, \& Ravinthar, 2017). Furthermore, Taiseer in his study suggested that, the study of error analysis is needed in the learning process because it helps the teachers to infer the nature of the learner's knowledge and by understanding the frequency of the students' errors would enable the teachers to teach the point of errors. Errors provide evidence and feedback, they show the teachers what part of the syllabus have been following that inadequately learned and taught and what needs further attention (Hourani, 2008).

\section{Method}

This research was aimed to find out which type of errors, in terms of omission, addition, selection and ordering that is committed most frequently by students in writing procedure texts and to find out the significant difference in the errors committed by the students when grouped according to gender. Relating to this, the researcher used quantitative research. According to Kothari, quantitative research is a research that discovers issues and the result is presented in the form of number (Kothari, 2004). Quantitative research is a research technique that is used to gather quantitative data information dealing with numbers and anything that is measurable and also known as quantitative data. Statistics, graphs and tables are often used to present the results of this method (Nunan \& Carter, 2001). Since the present research is a comparative research of errors in the English writing of students, therefore, a quantitative method was appropriate for this research.

Population can be defined as the entire and broader group of people, or objects that would like to use by the researcher to draw conclusions and the results of the study (Wallen \& Fraenkel, 2013). The population was ninth grade students in Pangkalpinang. It consists of three classes. The total number of 
population was 118 students. In taking the sample of this research, every student has a chance of being selected in the sample. Therefore, random sampling was used by the researcher because these classes had the same syllabus, materials, teaching methodology and all classes could be represented as the samples in this research. According to Arikunto, if the sample is less than 100, it would be much better for the researcher to take all as the sample. But if the total subject outgrow, the subject could be taken $10-25 \%$ or $20-25 \%$ or more as the sample (Press, n.d.). Therefore, the researcher took $25 \%$ (30 students) would be the sample of this research which would be divided into 15 males and 15 females.

In analyzing the data, the researcher used the procedure as follows:

1. The researcher asked the rater to identify and quantify students' errors in terms of omission, addition, selection and ordering.

2. The researcher presented the data in charts, tables and in terms of percentages, frequencies, and ranks.

3. The researcher found the percentages, frequencies of students' errors from as formula below (Bluman, 2013):

$$
\left\{p=\frac{n 1}{\sum n} \times 100 \%\right\}
$$

$\begin{array}{lll}\text { Note: } & & \\ \mathbf{n} 1 & = & \text { Total of errors } \\ \sum \mathbf{n} & = & \text { Total of the whole errors }\end{array}$

4. After getting the whole errors, $t$-test was used to find out the significant difference in the errors committed by the students when grouped according to gender. The formula of $t$-test as follows:

$$
t=\frac{\bar{X}_{1}-\bar{X}_{2}}{\sqrt{\frac{\left(n_{1}-1\right) s_{1}^{2}+\left(n_{2}-1\right) s_{2}^{2}}{n_{1}+n_{2}-2}\left(\frac{1}{n_{1}}+\frac{1}{n_{2}}\right)}}
$$

\section{Results}

The main purpose of this research was to analyze and explore the grammatical errors committed by male and female students at the third grade in writing procedure texts and to find out the significant difference in the errors committed by the students when grouped according to gender. In accordance with the result analysis, the study revealed two major findings, as follows:

\section{The Types and Total Errors' Students}

An analysis of students' written work indicated several grammatical errors in terms of addition, omission, selection and ordering. The detailed information is presented below:

\section{a. Addition}

Where the element is present and which should not be there in a sentence. Narrowly, the students added some unnecessary elements. Some examples of errors are presented below:

Table 1

Students' Addition Errors

\begin{tabular}{|c|l|}
\hline No & \multicolumn{1}{c|}{ Sentences } \\
\hline 1 & I always eats a noodle pizza every morning. (eat) \\
\hline 2 & To prepare a pan. (prepare a pan) \\
\hline 3 & $\begin{array}{l}\text { Making sure that the USB cable is connected to your computer } \\
\text { (make sure) }\end{array}$ \\
\hline
\end{tabular}

As shown in table 1, the students performed few addition errors in their sentences. In number 1 , the student added an unnecessary tense marker such $s$ in her or his sentence. In addition, in number 2, the student added preposition to in her or his sentence, makes the sentence ungrammatical in English. Furthermore, in number 3, the student committed error in using simple present tense. 
Table 1.1

The Comparison of Male and Female Students' Addition Errors

\begin{tabular}{|c|c|c|}
\hline Group & Total & Percentage \\
\hline Male & 158 & $29.2 \%$ \\
\hline Female & 96 & $17.7 \%$ \\
\hline
\end{tabular}

As seen in Table 1.1, the male students committed 158 addition errors with the percentage of $29.2 \%$, while the female students committed 96 addition errors with the percentage of $17.7 \%$. The result of students' written work revealed that, addition errors were highly committed by male students.

\section{b. Omission}

Another ungrammatical error was observed in this study was the errors of omission. Where the element is omitted by the students which should be present in a sentence such as, the omission of $s / e s / i e s$. Thus, the omission errors appeared when the students omitted some the elements from their sentences. For example:

Table 2

Students' Omission Errors

\begin{tabular}{|c|l|}
\hline No & \multicolumn{1}{c|}{ Sentences } \\
\hline 1 & So have any idea how to make it? (do you) \\
\hline 2 & It so easy (is) \\
\hline 3 & Open file that you want to print. (the) \\
\hline
\end{tabular}

As shown in Table 2, the students performed few omission errors in their sentences. In number 1 , the student missed her or his subject and auxiliary verb for her or his yes or no question. In number 2, on the other hand, the student omitted the copula is in her or his sentence, which functions as the main verb in affirmative statements, makes the sentence ungrammatical in English. Furthermore, in number 3, the student omitted the article the.

Table 2.2

The Comparison of Male and Female Students' Omission Errors

\begin{tabular}{|c|c|c|}
\hline Group & Total & Percentage \\
\hline Male & 118 & $21.8 \%$ \\
\hline Female & 74 & $13.6 \%$ \\
\hline
\end{tabular}

As seen in Table 2.2, the male students committed 118 omission errors with the percentage of $21.8 \%$, while the female students committed 74 omission errors with the percentage of $13.6 \%$. It can be concluded that, the highest error of omission was committed by male students.

\section{c. Selection}

Errors of selection occurred when the students chose the wrong forms of the words place of the right ones. For example:

Table 3

Students' Selection Errors

\begin{tabular}{|c|l|}
\hline No & \multicolumn{1}{|c|}{ Sentences } \\
\hline 1 & And then, cut the onions (chop) \\
\hline 2 & Put mie in the bowl (Noodle) \\
\hline 3 & $\begin{array}{l}\text { After that, check weather the printer's name is same like you want to use } \\
\text { (whether) }\end{array}$ \\
\hline
\end{tabular}

As seen in table 3 , the students chose the wrong forms of the words place of the right ones. In number 1, the student chose cut instead of chop, in number 2, on the other hand, the student chose 
mie instead of noodle. Another error that the student exhibited in her or his sentence was weather instead of whether.

Table 3.1

The Comparison of Male and Female Students' Selection Errors

\begin{tabular}{|c|c|c|}
\hline Group & Total & Percentage \\
\hline Male & 34 & $6.2 \%$ \\
\hline Female & 25 & $4.6 \%$ \\
\hline
\end{tabular}

As shown in table 3.1, the male students committed 34 selection errors with the percentage of $6.2 \%$, while the female students committed 25 selection errors with the percentage of $4.6 \%$. It revealed that, the selection errors were highly committed by male students.

\section{d. Ordering}

Where the elements presented by the students are correct but wrongly sequenced. Some examples of error are presented below:

Table 4

Students' Ordering Errors

\begin{tabular}{|c|l|}
\hline No & \multicolumn{1}{c|}{ Sentences } \\
\hline 1 & After that, check your cable USB. (USB cable) \\
\hline 2 & Put the noodles into water hot. (hot water). \\
\hline
\end{tabular}

In number 1 , the student wrote the correct elements but wrongly sequenced, she or he ordered the words of cable $\boldsymbol{U S B}$ instead of $\boldsymbol{U S B}$ cable. In addition, in number 2, the student ordered the words of water hot instead of hot water.

Table 4.1

The Comparison of Male and Female Students' Ordering Errors

\begin{tabular}{|c|c|c|}
\hline Group & Total & Percentage \\
\hline Male & 23 & $4.2 \%$ \\
\hline Female & 13 & $2.4 \%$ \\
\hline
\end{tabular}

As seen in Table 4.1, the male students committed 23 ordering errors with the percentage of $4.2 \%$, while the female students committed 13 ordering errors with the percentage of $2.4 \%$. It showed that, the highest error of ordering was committed by male students.

\footnotetext{
Addition: $\frac{254}{541} \times 100 \%=47 \%$

Omission: $\frac{192}{541} \times 100 \%=35.4 \%$

Selection: $\frac{59}{541} \times 100 \%=10.9 \%$

Ordering: $\frac{36}{541} \times 100 \%=6.6 \%$
}

Table 5

The Total Male and Female Students' Errors

\begin{tabular}{|c|c|c|c|c|c|c|}
\hline Group & Addition & Omission & Selection & Ordering & Total & Percentage \\
\hline Male & 158 & 118 & 34 & $\mathbf{2 3}$ & $\mathbf{3 3 3}$ & $\mathbf{6 1 . 5 \%}$ \\
\hline Female & 96 & 74 & 25 & $\mathbf{1 3}$ & $\mathbf{2 0 8}$ & $\mathbf{3 8 . 5 \%}$ \\
\hline TOTAL & $\mathbf{2 5 4}$ & $\mathbf{1 9 2}$ & $\mathbf{5 9}$ & $\mathbf{3 6}$ & $\mathbf{5 4 1}$ & $\mathbf{1 0 0 \%}$ \\
\hline
\end{tabular}


As seen in Table 5, the male students committed 158 addition errors with the percentage of $29.2 \%$, while the female students committed 96 addition errors with the percentage of $17.7 \%$. Then, the male students committed 118 omission errors with the percentage of $21.8 \%$, while the female students committed 74 omission errors with the percentage of $13.6 \%$. Furthermore, the male students committed 34 selection errors with the percentage of $6.2 \%$, while the female students committed 25 selection errors with the percentage of $4.6 \%$. In addition, the male students committed 23 ordering errors with the percentage of $4.2 \%$, while the female students committed 13 ordering errors with the percentage of $2.4 \%$. The result of students' written work revealed that, the errors were highly committed by male students.

Figure 1

The Types of Errors

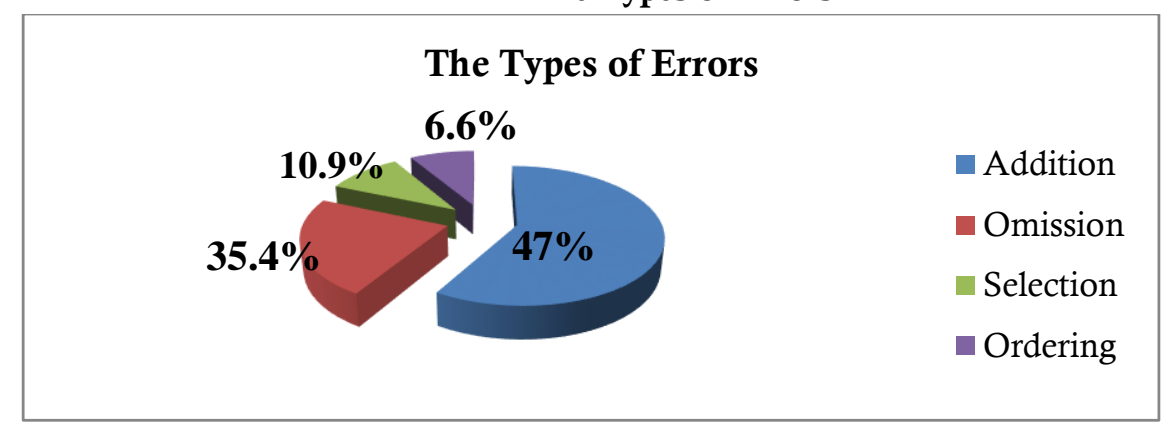

\section{Test of Difference in the Errors Committed by Male and Female Students}

Table 6

Paired Samples Statistics

\begin{tabular}{|ll|r|r|r|r|}
\hline & & & & \\
& & Mean & $\mathrm{N}$ & \multicolumn{1}{c|}{ Std. Deviation } & Std. Error Mean \\
\hline Pair & Male & 22.20 & 15 & 2.541 & .656 \\
1 & Female & 13.87 & 15 & 2.900 & .749 \\
\hline
\end{tabular}

In accordance with the paired samples statistics table, it showed that the difference in the errors committed by male and female students. The obtained mean error of male was 22.20 with SD was 2.541 while the female students obtained an average mean of 13.87 with SD 2.900, with the mean difference of 8.333 between two groups.

Table 6.1

Paired Samples Correlations

\begin{tabular}{|l|r|r|r|}
\hline & $\mathrm{N}$ & Correlation & \multicolumn{1}{|c|}{ Sig. } \\
\hline Pair 1 Male \& Female & 15 & -.074 & .794 \\
\hline
\end{tabular}

In the result of Paired samples correlation above, it showed that the correlation between male and female students was 0.074 with probability (sig) error was 0.794 
Table 6.2

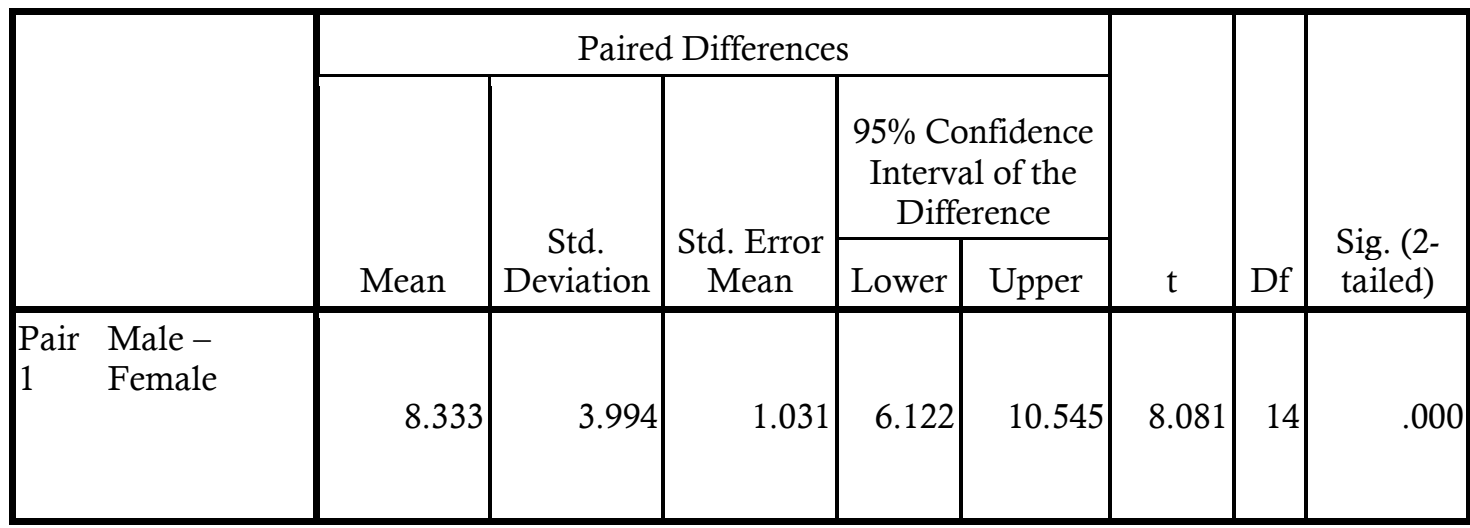

On the light with the table 6.2 above, it showed that the mean between male and female was 8.333, with standard deviation (SD) was 3.994, standard error mean was 1.031 and t-obtained was 8.081 , at the significant level of $\mathrm{p}<0.05$ for two tailed test and with degree of freedom (DF) 14 (2.14). Since the t-obtained was greater than t-table $(8.081>2.14)$ and the significant $(2$ tailed) was lower than computation with level significant $(0.000<0.05)$, Therefore, the null hypotheses $\left(\mathrm{H}_{0}\right)$ was rejected and the alternative hypotheses $\left(\mathrm{H}_{\mathrm{a}}\right)$ was accepted. The result showed that there was a significant difference between the errors committed by the students when grouped according to gender.

\section{Discussions}

In accordance with the findings, we have a visual that in students' written work indicated several grammatical errors such as, omission, addition, selection and ordering in subject verb agreement in simple present tense, preposition, article and spelling. In the light of the tables above, the students often committed errors in writing procedure texts. The students were mainly confused in choosing the right words. Therefore, if the teachers do not teach strategies to assist students in comprehending the basis rule of standard English, these students will continue to make such errors in their education even when they would like to continue on their study in the future. Furthermore, the study of error analysis helps teachers to find out the problematic areas of headline language at different levels of instruction and then, it is crucial for the teachers to emphasize lessons and the number of assignments in improving student's ability especially in writing.

The study of error analysis is like a clue for the teachers pinpoint the learning problems that are faced by the students. In teaching English in the classroom, the teachers need to give an opportunity to the students to work in a group to improve their writing ability. Error analysis would help the teachers to understand the students' weakness and error and it informs the teachers to modify their teaching style based on what students' need. On the other hand, the issue about gender differences has received considerable attention in the context of foreign or second language learning and teaching, there are few studies on the relationship between gender and EFL students' written errors have been carried out. On the light of findings, the result of samples test of students' errors, the t-obtained was 8.081 with the significant ( 2 tailed) was 0.000 . Since, the t-obtained was greater than t-table $(8.081>2.14)$ and the significant $(2$ tailed) was lower than computation with level significant $(0.000<0.05)$, Therefore, the null hypotheses $\left(\mathrm{H}_{0}\right)$ was rejected and the alternative hypotheses $\left(\mathrm{H}_{\mathrm{a}}\right)$ was accepted. The result showed that there was a significant difference between the errors committed by the students when grouped according to gender. 
From the table 5, it shows that, addition errors made up the most of errors in students' written work with the percentage was $47 \%$. The number of students' omission errors was $35.4 \%$, the number of students' selection errors was $10.9 \%$ and followed by students' ordering errors was $6.6 \%$. Based on the result of paired samples test of students' errors, the t-obtained was 8.081 with the significant ( 2 tailed) was 0.000 . Since, the t-obtained was greater than $\mathrm{t}$-table $(8.081>2.14)$ and the significant $(2$ tailed) was lower than computation with level significant $(0.000<0.05)$, Therefore, the null hypotheses $\left(\mathrm{H}_{0}\right)$ was rejected and the alternative hypotheses $\left(\mathrm{H}_{\mathrm{a}}\right)$ was accepted. The result showed that there was a significant difference between the errors committed by the students when grouped according to gender.

\section{Conclusions}

The study of error analysis helps teachers to find out the problematic areas of headline language at different levels of instruction and then, it is crucial for the teachers to emphasize lessons and the number of assignments in improving student's ability especially in writing. The teachers need to give a chance to the students to practice together to increase students' writing skill by implementing team work and get them to work in groups on their projects. The study of error provides feedback, therefore, by understanding the students' weakness and error that would help the teachers to modify their teaching style based on what students' need. In the meantime, the teachers should identify the errors after giving the students assignments in order to help the teachers to find out what part of the syllabus have been following that inadequately learned and taught and what needs further attention. The results above revealed two major findings, as follows:

First, teaching and learning are both complex process in the classroom. While the results of the present research have given an insight into what types of errors are commonly committed by the students and their frequency of occurrence. Furthermore, addition errors made up the most of errors in students' written work in which they were mainly confused about preposition and subject verb agreement with the percentage was $47 \%$. The number of students' omission errors was $35.4 \%$, the number of students' selection errors was $10.9 \%$ and followed by students' ordering errors was $6.6 \%$.

Second, based on the result of paired samples test of students' errors, the t-obtained was 8.081 with the significant $(2$ tailed) was 0.000 . Since, the $t$-obtained was greater than $t$-table $(8.081>2.14)$ and the significant $(2$ tailed) was lower than computation with level significant $(0.000<0.05)$, Therefore, the null hypotheses $\left(\mathrm{H}_{0}\right)$ was rejected and the alternative hypotheses $\left(\mathrm{H}_{\mathrm{a}}\right)$ was accepted. The result showed that there was a significant difference between the errors committed by the students when grouped according to gender.

\section{References}

Blakemore, J. E. O., Berenbaum, S. A., \& Liben, L. S. (2013). Gender development. Psychology Press.

Bluman, A. G. (2013). Elementary statistics: A step by step approach: A brief version. McGraw-Hill.

Brown, H. D. (2000). Principles of language learning and teaching (Vol. 4). Longman New York.

Cameron, D. (2010). Sex/gender, language and the new biologism. Applied Linguistics, 31(2), 173-192.

David, N. (1991). Language teaching methodology. Printice Hall, New York, London, Toronto, Sydney, Tokyo, Singapore.

Eckert, P., \& McConnell-Ginet, S. (2003). Language and Gender Text.

Holmes, J., \& Meyerhoff, M. (2008). The handbook of language and gender (Vol. 25). John Wiley \& Sons.

Holmes, M. (2007). What is gender?: Sociological approaches. Sage. 
Hourani, T. M. Y. (2008). An analysis of the common grammatical errors in the English writing made by 3rd secondary male students in the Eastern Coast of the UAE.

Kothari, C. R. (2004). Research methodology: Methods and techniques. New Age International.

Larsen-Freeman, D., \& Long, M. H. (2014). An introduction to second language acquisition research. Routledge.

Lynch, T., \& Anderson, K. (2013). Grammar for academic writing. English Language Teaching Centre. University of Edinburgh.

Marianne, B. (2011). New perspectives on gender. In Handbook of labor economics (Vol. 4, pp. 1543-1590). Elsevier.

Martin, C. L., \& Ruble, D. N. (2010). Patterns of gender development. Annual Review of Psychology, 61, 353-381.

Meyerhoff, M., \& Holmes, J. (2003). The handbook of language and gender. Blackwell Publishing Ltd.

Nunan, D., \& Carter, R. (2001). The Cambridge guide to teaching English to speakers of other languages. Ernst Klett Sprachen.

Press, Z. (n.d.). Al-Qur'an dan terjemahnya. 2004. Departemen Agama Republik Indonesia: Bandung: Diponegoro Arikunto. Suharsimi. 2010. Prosedur Penelitian: Suatu Pendekatan Praktek. Jakarta: Rineka Cipta Franklin. 2003. Tourism An Introduction. Available at.

Quibol-Catabay, M. (2016). Error analysis on students' writing. International Journal of Advanced Research in Management and Social Sciences, 5(1), 131-148.

Rocheleau, D., Thomas-Slayter, B., \& Wangari, E. (2016). Gender and the Environment (Vol. 3). NYU Press.

Ruble, D. N., Martin, C. L., \& Berenbaum, S. A. (2007). Gender development. Handbook of Child Psychology, 3.

Saaristo, P. (2015). Grammar is the heart of language: grammar and its role in language learning among Finnish university students. Voices of Pedagogical Development-Expanding, Enhancing and Exploring Higher Education Language Learning, 279-318.

Singh, C. K. S., Singh, A. K. J., Razak, N. Q. A., \& Ravinthar, T. (2017). Grammar Errors Made by ESL Tertiary Students in Writing. English Language Teaching, 10(5), 16-27.

Wallen, N. E., \& Fraenkel, J. R. (2013). Educational research: A guide to the process. Routledge. 